\title{
Radiological Society of North America
} (RSNA) 3D Printing Special Interest Group

David H. Ballard ${ }^{1 *}$ D, Nicole Wake ${ }^{2}$, Jan Witowski ${ }^{3}$, Frank J. Rybicki ${ }^{4}$, Adnan Sheikh ${ }^{5}$ and RSNA Special Interest Group for 3D Printing Abdominal, Hepatobiliary, and Gastrointestinal Conditions Voting Group

\begin{abstract}
Background: Medical 3D printing has demonstrated value in anatomic models for abdominal, hepatobiliary, and gastrointestinal conditions. A writing group composed of the Radiological Society of North America (RSNA) Special Interest Group on 3D Printing (SIG) provides appropriateness criteria for abdominal, hepatobiliary, and gastrointestinal 3D printing indications.

Methods: A literature search was conducted to identify all relevant articles using 3D printing technology associated with a number of abdominal pathologic processes. Each included study was graded according to published guidelines.

Results: Evidence-based appropriateness guidelines are provided for the following areas: intra-hepatic masses, hilar cholangiocarcinoma, biliary stenosis, biliary stones, gallbladder pathology, pancreatic cancer, pancreatitis, splenic disease, gastric pathology, small bowel pathology, colorectal cancer, perianal fistula, visceral trauma, hernia, abdominal sarcoma, abdominal wall masses, and intra-abdominal fluid collections.
\end{abstract}

Conclusion: This document provides initial appropriate use criteria for medical 3D printing in abdominal, hepatobiliary, and gastrointestinal conditions.

\footnotetext{
* Correspondence: davidballard@wustl.edu

${ }^{1}$ Mallinckrodt Institute of Radiology, Washington University School of

Medicine, 510 S. Kingshighway Blvd, Campus Box 8131, St. Louis, MO 63110,

USA

Full list of author information is available at the end of the article
}

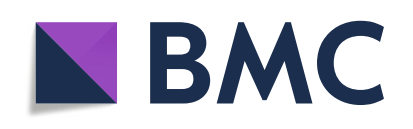

( ) The Author(s). 2020 Open Access This article is licensed under a Creative Commons Attribution 4.0 International License, which permits use, sharing, adaptation, distribution and reproduction in any medium or format, as long as you give appropriate credit to the original author(s) and the source, provide a link to the Creative Commons licence, and indicate if changes were made. The images or other third party material in this article are included in the article's Creative Commons. licence, unless indicated otherwise in a credit line to the material. If material is not included in the article's Creative Commons licence and your intended use is not permitted by statutory regulation or exceeds the permitted use, you will need to obtain permission directly from the copyright holder. To view a copy of this licence, visit http://creativecommons.org/licenses/by/4.0/ The Creative Commons Public Domain Dedication waiver (http://creativecommons.org/publicdomain/zero/1.0/) applies to the data made available in this article, unless otherwise stated in a credit line to the data. 


\section{Background}

In 2018, the Radiological Society of North America (RSNA) Special Interest Group on 3D Printing (SIG) published initial guidelines for medical 3D printing appropriateness [1]. Those appropriateness guidelines included a number of organ or system-based appropriateness criteria; however, they did not include indications for abdominal, hepatobiliary, and gastrointestinal 3D printing. Medical 3D printing has been gaining popularity in new areas of clinical practice and is now performed for a variety of abdominal indications [2]. However, there is no consensus on which abdominal, hepatobiliary, and gastrointestinal scenarios and indications can most benefit from 3D printing. The purpose of this work is to provide evidence-based appropriate use criteria for abdominal, hepatobiliary, and gastrointestinal indication for medical 3D printing.

\section{Methods}

The SIG initiated writing groups for appropriateness of performing $3 \mathrm{D}$ printing from medical imaging for various clinical conditions. This present work provides the literature search and strength of evidence to introduce the appropriateness of abdominal, hepatobiliary, and gastrointestinal 3D printing for clinical utilization, research, scientific, and informational purposes. Related work previously published and not covered in the present work includes genitourinary and abdominal vascular conditions, which were presented in the initial appropriateness guidelines [1]. This work is loosely modeled after the American College of Radiology (ACR) Appropriateness Criteria $^{\circ}$ [3], in that the guidelines committee uses an evidence-based approach at scoring. Consensus among members is used when there is a paucity of evidence. Strength of evidence is determined by literature review.

The SIG Guidelines Chairperson oversees the ratings via a vote among Special Interest Group members at inperson meetings. The results of the ratings follow the following 1-9 format (with 9 being the most appropriate):

$1-3$, red, rarely appropriate: There is a lack of a clear benefit or experience that shows an advantage over usual practice.

4-6, yellow, may be appropriate: There may be times when there is an advantage, but the data is lacking, or the benefits have not been fully defined.

7-9, green, usually appropriate: Data and experience shows an advantage to 3D printing as a method to represent and/or extend the value of data contained in the medical imaging examination.

Clinical scenarios were organized by organ systems. An exhaustive PubMed literature search was performed through October 2018, a strength of evidence analysis was performed, and an appropriate use criteria document was generated. The supporting evidence was obtained through structured PubMed searches, as detailed in the Appendix 1. For each category, from the pool of total results, the number of publications considered "included results" was initially curated by a single author with expertise in 3D printing and abdominal imaging (DHB) then substantiated by consensus of coauthors with expertise in $3 \mathrm{D}$ printing. For the present study, only anatomic models were included for evaluation. The following categories were excluded because they were considered outside the project scope: virtual and augmented reality, 3D printed implants, 3D printed instruments and surgical guides, bioprinting, and bioactive printing. Abdominal 3D printing review articles were recorded, but not considered in determining final appropriateness ratings. All final components of this section were vetted and approved by vote of Special Interest Group members face-to-face at the 2018 Annual Meeting of the Radiological Society of North America (November 27, 2018, Chicago, IL, USA). Afterwards, a 2week period for comments by SIG member was posted on the SIG's members-only online forum. In addition, all included studies [4-49] were graded with a strength of evidence assessment according to ACR Appropriateness Criteria Evidence Document [50].

\section{Results}

Table 1 provides evidence-based guidelines, supplemented by expert opinion when there was a paucity of peer-review data, to define and support the use of 3D printing for patients with abdominal, hepatobiliary, and gastrointestinal conditions. The citations included in forming the appropriateness criteria and the strength of evidence assessment are presented in Appendices 1 and 2 respectively.

\section{Discussion}

\section{Hepatobiliary}

The majority of intrahepatic masses requiring resection in adults includes hepatocellular carcinoma and isolated or few intrahepatic metastases, such as colorectal metastasis [51]. Anatomic models have been used in preoperative planning for surgical resection of hepatic masses [19, 21, 52]. Specifically, 3D printed anatomic models may be helpful in the resection of hepatic tumors through demonstrating the relationship of the tumor in regards to its location within hepatic segments, invasion or proximity to major hepatic or portal veins, arteries, and bile ducts. Printed models can help in choosing the optimal resection plane and may be useful in selecting patients at risk of posthepatectomy liver failure. Additionally, anatomic models have been used for both liver transplant donor and recipients [20].

Biliary obstruction has benign and malignant etiologies including strictures, extrinsic compression, stones, and biliary malignancies. Symptomatic patients or those with 
Table 1 Appropriateness Ratings for Abdominal, Hepatobiliary, and Gastrointestinal Indications. The "Rating driven..." column denotes if the primary decision for the condition's rating was decided primarily through results and discussion of the literature search or expert opinion (the latter was largely reserved for conditions with no or few supporting studies). The "Study quality" column reflects the graded strength of evidence assessment according to ACR Appropriateness Criteria Evidence Document ${ }^{50}$ (individual ratings available in Appendix 2). The highest/most robust level of evidence is 'Category 1' and the lowest is 'Category 4.' No studies qualified for Category 1, but multiple did qualify for Category 2

\begin{tabular}{|c|c|c|c|c|c|c|}
\hline Clinical Condition & Rating & $\begin{array}{l}\text { Rating driven by } \\
\text { literature appraisal } \\
\text { or expert opinion }\end{array}$ & References & Study quality & $\begin{array}{c}\text { Number of } \\
\text { patients } \\
\text { (combined) }\end{array}$ & $\begin{array}{l}\text { Number of } \\
\text { patients in } \\
\text { largest } \\
\text { series } \\
\text { (reference) }\end{array}$ \\
\hline \multicolumn{7}{|l|}{$\begin{array}{l}\text { HEPATOBILIARY } \\
\text { PATHOLOGY }\end{array}$} \\
\hline $\begin{array}{l}\text { Intra-hepatic masses } \\
\text {-Surgical management } \\
\text {-Percutaneous } \\
\text { management }\end{array}$ & $\begin{array}{l}8 \\
4\end{array}$ & $\begin{array}{l}\text { Both } \\
\text { Literature } \\
\text { appraisal }\end{array}$ & 4-28 & $\begin{array}{l}\text { Category 2: } 4 \text { studies } \\
\text { Category 3: } 5 \text { studies } \\
\text { Category 4: } 16 \text { studies }\end{array}$ & $\begin{array}{c}151 \\
\text { patients }\end{array}$ & $\begin{array}{c}32 \\
\text { patients } \\
(19)\end{array}$ \\
\hline \multicolumn{7}{|l|}{ Biliary pathology } \\
\hline $\begin{array}{l}\text {-Hilar cholangiocarcnoma } \\
\text {-Stenosis, benign and } \\
\text { malignant } \\
\text {-Biliary stones (simple and } \\
\text { complex) } \\
\text {-Simple } \\
\text {-Complex }\end{array}$ & $\begin{array}{l}5 \\
3\end{array}$ & $\begin{array}{l}\text { Literature appraisal } \\
\text { Both }\end{array}$ & $\begin{array}{c}6,15,19,29- \\
31\end{array}$ & $\begin{array}{l}\text { Category } 2: 1 \text { study } \\
\text { Category 3: } 3 \text { studies } \\
\text { Category } 4: 2 \text { studies }\end{array}$ & 48 patients & $\begin{array}{l}32 \text { patients } \\
\text { (19) }\end{array}$ \\
\hline Gallbladder pathology & 1 & Expert opinion & \multicolumn{4}{|c|}{ No results from literature search and inclusion criteria } \\
\hline \multicolumn{7}{|l|}{ PANCREATIC DISEASE } \\
\hline Pancreatic adenocarcinoma & 5 & Literature appraisal & $32-40$ & $\begin{array}{l}\text { Category 3: } 4 \text { studies } \\
\text { Category 4: } 5 \text { studies }\end{array}$ & 13 patients & $\begin{array}{c}10 \\
\text { patients } \\
(37)\end{array}$ \\
\hline $\begin{array}{l}\text { Pancreatic mucous or cystic } \\
\text { neoplasms }\end{array}$ & 3 & Literature appraisal & 40 & Category 4: 1 study & & \\
\hline Pancreatitis & 1 & Expert opinion & \multicolumn{4}{|c|}{ No results from literature search and inclusion criteria } \\
\hline SPLENIC DISEASE & 3 & Literature appraisal & 35,40 & $\begin{array}{l}\text { Category 3: } 1 \text { study } \\
\text { Category } 4: 1 \text { study }\end{array}$ & 22 patients & $\begin{array}{c}12 \\
\text { patients } \\
(40)\end{array}$ \\
\hline \multicolumn{7}{|l|}{$\begin{array}{l}\text { GASTROINTESTINAL TRACT } \\
\text { PATHOLOGY }\end{array}$} \\
\hline Gastric pathology & 3 & Literature appraisal & $30,41-43$ & $\begin{array}{l}\text { Category 3: } 3 \text { studies } \\
\text { Category } 4: 1 \text { study }\end{array}$ & $\begin{array}{r}\begin{array}{r}\text { No patients } \\
\text { and lapa } \\
\text { simu }\end{array}\end{array}$ & $\begin{array}{l}\text { endoscopy } \\
\text { roscopic } \\
\text { lators }\end{array}$ \\
\hline Small bowel pathology & 1 & Expert opinion & \multicolumn{4}{|c|}{ No results from literature search and inclusion criteria } \\
\hline Colorectal cancer & 5 & Literature appraisal & $44-47$ & $\begin{array}{l}\text { Category } 3: 2 \text { studies } \\
\text { Category } 4: 2 \text { studies }\end{array}$ & 30 patients & $\begin{array}{c}22 \\
\text { patients } \\
(45)\end{array}$ \\
\hline Perianal/perirectal fistula & 4 & Literature appraisal & 48 & Category 4: 1 study & 3 patients & $\begin{array}{l}3 \text { patients } \\
(48)\end{array}$ \\
\hline $\begin{array}{l}\text { VISCERAL TRAUMA } \\
\text { (excluding vascular } \\
\text { conditional managed } \\
\text { endovascularly, fractures, } \\
\text { and genitourinary trauma) }\end{array}$ & 1 & Expert opinion & \multicolumn{4}{|c|}{ No results from literature search and inclusion criteria } \\
\hline \multicolumn{7}{|l|}{$\begin{array}{l}\text { MISCELLANEOUS } \\
\text { ABDOMINAL CONDITIONS }\end{array}$} \\
\hline Hernias & 2 & Literature appraisal & 49 & Category 4: 1 study & $\begin{array}{r}\text { No pa } \\
\text { laparoscop }\end{array}$ & $\begin{array}{l}\text { ients - } \\
\text { ic simulator }\end{array}$ \\
\hline $\begin{array}{l}\text { Abdominal, abdominal wall, } \\
\text { or sarcomas }\end{array}$ & 2 & Expert opinion & \multicolumn{4}{|c|}{ No results from literature search and inclusion criteria } \\
\hline Retroperitoneal sarcomas & 4. & Expert opinion & \multicolumn{4}{|c|}{ No results from literature search and inclusion criteria } \\
\hline Abdominal wall masses & 2 & Expert opinion & \multicolumn{4}{|c|}{ No results from literature search and inclusion criteria } \\
\hline $\begin{array}{l}\text { Intra-abdominal fluid } \\
\text { collections }\end{array}$ & 1 & Expert opinion & \multicolumn{4}{|c|}{ No results from literature search and inclusion criteria } \\
\hline
\end{tabular}

laboratory derangements of obstructive jaundice or liver dysfunction may benefit from endoscopic stones and sludge removal, dilation, and stenting in select cases [53]. For biliary endoscopy, previous work show 3D printed anatomic models being used primarily in training applications $[29,30]$. 3D printing has been used in the development of novel biliary stents [54].

Laparoscopic cholecystectomy is among one of the most common operations performed by general surgeons, which may be performed in an acute setting for 
acute cholecystitis or electively for symptomatic cholelithiasis and other indications [55]. Percutaneous cholecystostomy is a percutaneous approach for management of acute cholecystitis, often performed in those who are critically ill or poor candidates for general anesthesia [56]. The gallbladder may infrequently be a site of primary malignancy, prompting cholecystectomy (often open and radical) in the absence of metastasis. Specific applications of $3 \mathrm{D}$ printed anatomic models related to the gallbladder have not been published through the extent of our literature search.

\section{Pancreas and spleen}

Pancreatic cancer is the fourth leading cause of cancer death in the United States and typically caries a poor prognosis with a 3\% 5-year survival rate [57]. Resections of pancreatic tumors are challenging operations with high rates of morbidity [58]. To this end, 3D printed anatomic models to delineate tumor anatomy may be of use and have been published in cases series for pancreatic cancer applications [34-37].

There are a number of mucinous and serous pancreatic neoplasms, some of which may be indicated for surgical resection [59]. One educational series fabricated a 3D printed anatomic model for a pancreatic tail mucinous neoplasm, although this was not used in the patient's preoperative planning [34].

Pancreatitis is an inflammatory response of the pancreas most commonly due to alcoholism and obstruction of the pancreatic duct. This condition is a clinical diagnosis by symptomatology and laboratory derangements. Imaging can be used to help confirm the diagnosis or assess for complications. Complications requiring percutaneous, endoscopic, and infrequently surgical management include infected peripancreatic fluid collections, walled off pancreatic necrosis, and other less frequent etiologies [60]. Specific applications of 3D printed anatomic models related to pancreatitis or its complications have not been published through the extent of our literature search.

Elective splenectomy is often performed for hematologic conditions, as part of larger operations (typically cancer adjacent cancer resections), or, rarely, due to splenic masses with indications for resection. There have been two cases series involving 3D printed anatomic models $[36,40]$, one of which was used in the process of patient consent [40].

\section{Gastrointestinal}

The incidence of gastric cancer has decreased worldwide with improved detection and treatment of Helicobacter pylori and availability of endoscopy. However, gastric cancer remains a morbid diagnosis and cause of cancer death [61]. Peptic ulcer disease is a prevalent condition, often treated medically and occasionally further characterized with endoscopy [53]. Published uses of anatomic models in gastric pathology largely encompass simulation of endoscopy or surgery [41, 42].

Small bowel tumors are relatively uncommon, most commonly due to adenocarcinoma, gastrointestinal stromal tumor, carcinoid tumor and lymphoma. These may present with abdominal pain, small bowel obstruction, or without symptoms [62]. In North America, small bowel obstruction most commonly occurs due to postoperative adhesions. Other causes include incarcerated hernias, strictures, and malignant obstruction [63]. Specific applications of 3D printed anatomic models related to small bowel pathology have not been published through the extent of the literature search.

Colorectal cancer is the third most common cause of cancer death in the United States [57]. Treatment strategies vary considerably according to anatomic location, staging, among other factors [64]. 3D printed anatomic models have shown some utility in delineating relevant surgical anatomy for resection of colorectal cancer $[45,46]$.

Anorectal fistulae and abscesses are abnormal tracts and collections about the anus and rectum that occur with greater frequency in patients with Crohn disease [65]. Frequently, pelvic MRI may be obtained to delineate anatomy for treatment planning. In one feasibility series, 3D printed models were used to demonstrate anatomy of anorectal fistulae [48].

\section{Visceral abdominal trauma}

Blunt and penetrating abdominal trauma may result in life-threatening visceral trauma requiring resuscitative efforts and exploratory laparotomy. With current 3D printing technology, the time needed to segment and print anatomic models is currently too lengthy for use in traumatic conditions requiring immediate treatment. Accordingly, our literature search yielded no relevant results regarding the use of 3D printed anatomic models in visceral abdominal trauma.

\section{Miscellaneous abdominal conditions}

Elective hernia repair is among the most common operations performed by general surgeons [66]. Diagnosis is often by physical examination and imaging infrequently plays a part in diagnosing hernias. However, although anatomic models have not been published for preoperative planning of hernias, 3D printing has facilitated a training system in one published series [49]. 3D printing technologies have been used in the design of novel surgical meshes $[67,68]$.

Sarcomas are aggressive tumors, often locally advanced at the time of diagnosis. They may occur anywhere in the body. In the abdomen, sarcomas may be retroperitoneal, intra-abdominal, or affect the abdominal wall [69]. Although 3D printed anatomic models could potentially be 
helpful in planning surgical approaches, our search yielded no results for abdominal sarcomas. One case series described anatomic models used for treatment planning in a mediastinal/intrathoracic sarcoma [70].

Abdominal wall masses are most frequently benign and include fibromatosis (desmoid tumor) and endometriosis. Malignant causes are most frequently metastases or sarcomas [69, 71]. Specific applications of 3D printed anatomic models related to abdominal wall masses have not been published through the extent of our literature search.

Intra-abdominal fluid collections with indications for drainage are frequently managed with image-guided percutaneous drainage [72]. There is often acuity in time to drainage, which may account for the lack of publications related to 3D printed anatomic models delineating intraabdominal fluid collections. Accordingly, our literature search yielded no results.

\section{Limitations}

Limitations of this work include its lack of objective data collection and inferential statistics. Although such an analysis would be desirable, it is not practical with most published abdominal, hepatobiliary, and gastrointestinal applications due to the small number of publications and patients. One exception is $3 \mathrm{D}$ printing in liver surgery, which does have a previously published systematic review [73]. PubMed search terms, as highlighted in Appendix 1 , were based on prior search terminology from previously published guidelines [1] and used ' $3 \mathrm{D}$ printing' or 'rapid prototyping' to capture 3D printing-related publications; it is possible some publications may have been missed without using additional terms such as 'three dimensional printing' or 'three-dimensional printing'. The RSNA 3D Printing SIG is comprised of physicians (primarily radiologists), imaging scientists, biomedical engineers, and other 3D printing experts, the voting group did not have direct input from general surgeons, gastroenterologists, or collaboration from a surgery or gastroenterology professional organization. Future iterations should aim for such collaboration.

\section{Conclusion}

This document provides initial appropriate use criteria for 3D printing in abdominal, hepatobiliary, and gastrointestinal conditions. Adoption of common clinical standards regarding appropriate use, information and material management, and quality control are needed to ensure the greatest possible clinical benefit from 3D printing [1]. With accruing evidence for value in 3D printing, recently implemented category III Current Procedural Terminology codes, and the upcoming ACR registry for 3D printing [74], it is anticipated that this consensus guideline document, created by the members of the RSNA 3D printing Special Interest Group, will provide a reference for clinical standards of 3D printing. The document will be periodically refined, based on expanding clinical applications and growing medical literature.

\section{Supplementary information}

Supplementary information accompanies this paper at https://doi.org/10. 1186/s41205-020-00065-6.

Additional file 1: Appendix 1. Literature search

Additional file 2: Appendix 2. Strength of Evidence

\section{Acknowledgements}

We acknowledge the inciteful collaboration of the Radiological Society of North America 3D printing Special Interest Group in the development of this document.

\section{Authors' contributions}

Every author listed above has been involved in design, data collection, interpretation, as well as manuscript drafting and editing. All authors read and approved the final manuscript.

Funding

No funding sources to declare for this study.

\section{Availability of data and materials}

The datasets used and/or analyzed during the current study are available from the corresponding author on reasonable request.

Ethics approval and consent to participate

Not applicable.

\section{Consent for publication}

Not applicable.

\section{Competing interests}

Dr. Ballard received salary support from National Institutes of Health TOP-TIER grant T32-EB021955 during the study period. Dr. Rybicki is the Medical Director of Imagia Cybernetics. All other authors claim no conflicts of interest or disclosures.

\section{Author details}

${ }^{1}$ Mallinckrodt Institute of Radiology, Washington University School of Medicine, 510 S. Kingshighway Blvd, Campus Box 8131, St. Louis, MO 63110 , USA. ${ }^{2}$ Department of Radiology, Montefiore Medical Center, Albert Einstein College of Medicine, Bronx, NY, USA. ${ }^{3}$ 2nd Department of General Surgery, Jagiellonian University Medical College, Kopernika 21, 31-501 Krakow, Poland. ${ }^{4}$ Department of Radiology, University of Cincinnati Medical Center, Cincinnati, OH, USA. ${ }^{5}$ Department of Radiology and The Ottawa Hospital Research Institute, University of Ottawa, Ottawa, ON, Canada.

Received: 8 January 2020 Accepted: 23 April 2020

Published online: 08 June 2020

References

1. Chepelev L, Wake N, Ryan J, et al. Radiological Society of North America (RSNA) 3D printing Special Interest Group (SIG): guidelines for medical 3D printing and appropriateness for clinical scenarios. 3D Print Med. 2018;4(1):11

2. Bastawrous S, Wake N, Levin D, Ripley B. Principles of three-dimensional printing and clinical applications within the abdomen and pelvis. Abdom Radiol (NY). 2018;43(10):2809-22.

3. ACR Appropriateness Criteria (2018) American college of radiology. https:// www.acr.org/Clinical-Resources/ACR-Appropriateness-Criteria. Accessed 2 Dec 2019

4. Igami T, Nakamura Y, Hirose T, et al. Application of a three-dimensional print of a liver in hepatectomy for small tumors invisible by intraoperative ultrasonography: preliminary experience. World J Surg. 2014;38(12):3163-6. 
5. Baimakhanov Z, Soyama A, Takatsuki M, et al. Preoperative simulation with a 3-dimensional printed solid model for one-step reconstruction of multiple hepatic veins during living donor liver transplantation. Liver Transpl. 2015; 21(2):266-8

6. Takagi K, Nanashima A, Abo T, et al. Three-dimensional printing model of liver for operative simulation in perihilar cholangiocarcinoma. Hepatogastroenterology. 2014;61(136):2315-6.

7. Souzaki $R$, Kinoshita $Y$, leiri $S$, et al. Three-dimensional liver model based on preoperative CT images as a tool to assist in surgical planning for hepatoblastoma in a child. Pediatr Surg Int. 2015;31(6):593-6.

8. Xiang N, Fang C, Fan Y, et al. Application of liver three-dimensional printing in hepatectomy for complex massive hepatocarcinoma with rare variations of portal vein: preliminary experience. Int J Clin Exp Med. 2015;8(10):18873-8.

9. Oshiro Y, Mitani J, Okada T, Ohkohchi N. A novel three-dimensional print of liver vessels and tumors in hepatectomy. Surg Today. 2017:47(4):521-4.

10. Soejima $Y$, Taguchi T, Sugimoto $M$, et al. Three-dimensional printing and biotexture modeling for preoperative simulation in living donor liver transplantation for small infants. Liver Transpl. 2016;22(11):1610-4.

11. Madurska MJ, Poyade M, Eason D, Rea P, Watson AJM. Development of a patient-specific 3D-printed liver model for preoperative planning. Surg Innov. 2017;24(2):145-50

12. Perica E, Sun Z. Patient-specific three-dimensional printing for pre-surgical planning in hepatocellular carcinoma treatment. Quant Imaging Med Surg. 2017;7(6):668-77.

13. Kuroda S, Kobayashi T, Ohdan H. 3D printing model of the intrahepatic vessels for navigation during anatomical resection of hepatocellular carcinoma. Int J Surg Case Rep. 2017:41:219-22.

14. Witowski JS, Pędziwiatr M, Major P, Budzyński A. Cost-effective, personalized, 3D-printed liver model for preoperative planning before laparoscopic liver hemihepatectomy for colorectal cancer metastases. Int J Comput Assist Radiol Surg. 2017;12(12):2047-54.

15. Yang Y, Zhou Z, Liu R, Chen L, Xiang H, Chen N. Application of 3D visualization and $3 D$ printing technology on ERCP for patients with hilar cholangiocarcinoma. Exp Ther Med. 2018;15(4):3259-64.

16. Choi YR, Kim JH, Park SJ, Hur BY, Han JK. Therapeutic response assessment using 3D ultrasound for hepatic metastasis from colorectal cancer: application of a personalized, 3D-printed tumor model using $C T$ images. PLoS One. 2017;12(8):e0182596.

17. Trout AT, Batie MR, Gupta A, Sheridan RM, Tiao GM, Towbin AJ. 3D printed pathological sectioning boxes to facilitate radiological-pathological correlation in hepatectomy cases. J Clin Pathol. 2017;70(11):984-7.

18. Yang T, Tan T, Yang J, et al. The impact of using three-dimensional printed liver models for patient education. J Int Med Res. 2018;46(4):1570-8.

19. Zeng N, Fang CH, Fan YF, et al. The construction of three-dimensional visualization platform and its application in diagnosis and treatment for hilar cholangiocarcinoma. Zhonghua Wai Ke Za Zhi. 2016;54(9):680-5.

20. Fang C, Fang Z, Fan Y, Li J, Xiang F, Tao H. Application of 3D visualization, $3 \mathrm{D}$ printing and $3 \mathrm{D}$ laparoscopy in the diagnosis and surgical treatment of hepatic tumors. Nan Fang Yi Ke Da Xue Xue Bao. 2015;35(5):639-45.

21. Zein NN, Hanouneh IA, Bishop PD, et al. Three-dimensional print of a liver for preoperative planning in living donor liver transplantation. Liver Transpl. 2013;19(12):1304-10

22. Hu M, Hu H, Cai W, et al. The safety and feasibility of three-dimensional visualization technology assisted right posterior lobe allied with part of $V$ and VIII Sectionectomy for right hepatic malignancy therapy. J Laparoendosc Adv Surg Tech A. 2018;28(5):586-94.

23. Wang J-Z, Xiong N-Y, Zhao L-Z, Hu J-T, Kong D-C, Yuan J-Y. Review fantastic medical implications of 3D-printing in liver surgeries, liver regeneration, liver transplantation and drug hepatotoxicity testing: a review. Int J Surg. 2018; 56:1-6.

24. Oshiro Y, Ohkohchi N. Three-dimensional liver surgery simulation: computer-assisted surgical planning with three-dimensional simulation software and three-dimensional printing<sup/>. Tissue Eng Part A. 2017; 23(11-12):474-80

25. Yao R, Xu G, Mao S-S, et al. Three-dimensional printing: review of application in medicine and hepatic surgery. Cancer Biol Med. 2016;13(4):443-51.

26. Alkhouri N, Zein NN. Three-dimensional printing and pediatric liver disease. Curr Opin Pediatr. 2016;28(5):626-30.

27. Witowski J, Wake N, Grochowska A, et al. Investigating accuracy of 3D printed liver models with computed tomography. Quant Imaging Med Surg. 2019;9(1):43-52.
28. Widmann G, Wallach D, Toporek G, Schullian P, Weber S, Bale R. Angiographic C-arm CT- versus MDCT-guided stereotactic punctures of liver lesions: nonrigid phantom study. AJR Am J Roentgenol. 2013; 201(5):1136-40.

29. Tang R, Ma L, Li A, et al. Choledochoscopic examination of a 3-dimensional printing model using augmented reality techniques: a preliminary proof of concept study. Surg Innov. 2018;25(5):492-8.

30. Holt BA, Hearn G, Hawes R, Tharian B, Varadarajulu S. Development and evaluation of a 3D printed endoscopic ampullectomy training model (with video). Gastrointest Endosc. 2015;81(6):1470-1475.e5.

31. Dhir $V$, Itoi T, Fockens $P$, et al. Novel ex vivo model for hands-on teaching of and training in EUS-guided biliary drainage: creation of "Mumbai EUS" stereolithography/3D printing bile duct prototype (with videos). Gastrointest Endosc. 2015;81(2):440-6.

32. Study Group of Pancreatic Surgery in Chinese Society of Surgery of Chinese Medical Association, Pancreatic Committee of Chinese Research Hospital Association, Digital Medicine Branch of Chinese Medical Association, Digital Medicine Committee of Chinese Research Hospital Association. Expert consensus of precise diagnosis and treatment for pancreatic head cancer using three-dimensional visualization technology. Zhonghua Wai Ke Za Zhi. 2017;55(12):881-6.

33. Yang $Y Y$, Huang $H G$. Development status of three-dimensional printing technology in pancreatic surgery. Zhonghua Wai Ke Za Zhi. 2017;55(10): 795-7.

34. Marconi S, Pugliese $L$, Botti $M$, et al. Value of $3 D$ printing for the comprehension of surgical anatomy. Surg Endosc. 2017;31(10):4102-10.

35. Sampogna G, Pugliese R, Elli M, Vanzulli A, Forgione A. Routine clinical application of virtual reality in abdominal surgery. Minim Invasive Ther Allied Technol. 2017;26(3):135-43.

36. Andolfi C, Plana A, Kania P, Banerjee PP, Small S. Usefulness of threedimensional modeling in surgical planning, resident training, and patient education. J Laparoendosc Adv Surg Tech A. 2017;27(5):512-5.

37. Marconi S, Pugliese L, Del Chiaro M, Pozzi Mucelli R, Auricchio F, Pietrabissa A. An innovative strategy for the identification and 3D reconstruction of pancreatic cancer from CT images. Updates Surg. 2016;68(3):273-8.

38. Zheng Y, Yu D, Zhao J, Wu Y, Zheng B. 3D printout models vs. 3D-rendered images: which is better for preoperative planning? J Surg Educ. 2016;73(3):518-23.

39. Mahmoud A, Bennett M. Introducing 3-dimensional printing of a human anatomic pathology specimen: potential benefits for undergraduate and postgraduate education and anatomic pathology practice. Arch Pathol Lab Med. 2015;139(8):1048-51.

40. Pietrabissa A, Marconi S, Peri A, et al. From CT scanning to 3-D printing technology for the preoperative planning in laparoscopic splenectomy. Surg Endosc. 2016;30(1):366-71.

41. Williams A, McWilliam M, Ahlin J, Davidson J, Quantz MA, Bütter A. A simulated training model for laparoscopic pyloromyotomy: is 3D printing the way of the future? J Pediatr Surg. 2018;53(5):937-41.

42. Lee S, Ahn JY, Han M, et al. Efficacy of a three-dimensional-printed training simulator for endoscopic biopsy in the stomach. Gut Liver. 2018;12(2):149-57

43. Kim GB, Park J-H, Song H-Y, et al. 3D-printed phantom study for investigating stent abutment during gastroduodenal stent placement for gastric outlet obstruction. 3D Print Med. 2017:3(1):10.

44. Garcia-Granero A, Sánchez-Guillén L, Fletcher-Sanfeliu D, et al. Application of three-dimensional printing in laparoscopic dissection to facilitate D3-lymphadenectomy for right colon cancer. Tech Coloproctol. 2018;22(2):129-33.

45. Luzon JA, Andersen BT, Stimec BV, et al. Implementation of 3D printed superior mesenteric vascular models for surgical planning and/or navigation in right colectomy with extended D3 mesenterectomy: comparison of virtual and physical models to the anatomy found at surgery. Surg Endosc. 2019:33(2):567-75

46. Hamabe A, Ito M. A three-dimensional pelvic model made with a threedimensional printer: applications for laparoscopic surgery to treat rectal cancer. Tech Coloproctol. 2017;21(5):383-7.

47. Tominaga $T$, Takagi $K$, Takeshita $H$, et al. Usefulness of three-dimensional printing models for patients with stoma construction. Case Rep Gastroenterol. 2016:10(1):57-62

48. Sahnan K, Adegbola SO, Tozer PJ, et al. Innovation in the imaging perianal fistula: a step towards personalised medicine. Therap Adv Gastroenterol. 2018;11:1756284818775060. 
49. Nishihara Y, Isobe Y, Kitagawa Y. Validation of newly developed physical laparoscopy simulator in transabdominal preperitoneal (TAPP) inguinal hernia repair. Surg Endosc. 2017;31(12):5429-35.

50. ACR Appropriateness Criteria ${ }^{\circledast}$ Evidence Document. Available at: https:// www.acr.org/-/media/ACR/Files/Appropriateness-Criteria/ EvidenceTableDevelopment.pdf. Accessed 10 Dec 2019.

51. Gani F, Thompson VM, Bentrem DJ, Hall BL, Pitt HA, Pawlik TM. Patterns of hepatic resections in North America: use of concurrent partial resections and ablations. HPB (Oxford). 2016;18(10):813-20.

52. Witowski J, Budzyński A, Grochowska A, Ballard DH, Major P, Rubinkiewicz M, Złahoda-Huzior A, Popiela TJ, Wierdak M, Pędziwiatr M. Decision-making based on 3D printed models in laparoscopic liver resections with intraoperative ultrasound: a prospective observational study. Eur Radiol. 2020;30(3):1306-12.

53. Peery AF, Dellon ES, Lund J, et al. Burden of gastrointestinal disease in the United States: 2012 update. Gastroenterology. 2012;143(5):1179-87.e3.

54. Boyer CJ, Boktor M, Samant H, White LA, Wang Y, Ballard DH, Huebert RC, Woerner JE, Ghali GE, Alexander JS. 3D Printing for Bio-Synthetic Biliary Stents. Bioengineering (Basel). 2019;6(1):E16. https://doi.org/10.3390/ bioengineering6010016.

55. Smith JP, Samra NS, Ballard DH, Moss JB, Griffen FD. Prophylactic antibiotics for elective laparoscopic cholecystectomy. Am Surg. 2018;84(4):576-80.

56. Bundy J, Srinivasa RN, Gemmete JJ, Shields JJ, Chick JFB. Percutaneous Cholecystostomy: long-term outcomes in 324 patients. Cardiovasc Intervent Radiol. 2018;41(6):928-34.

57. Siegel RL, Miller KD, Jemal A. Cancer statistics, 2018. CA Cancer J Clin. 2019; 69(1):7-34.

58. Dindo D, Demartines N, Clavien P-A. Classification of surgical complications: a new proposal with evaluation in a cohort of 6336 patients and results of a survey. Ann Surg. 2004;240(2):205-13.

59. Hashimoto M, Watanabe G, Matsuda M, Mori M. Serous cystic neoplasm of the pancreas-indications for surgery. Hepatogastroenterology. 2006; 53(72):950-2.

60. Whitcomb DC. Clinical practice. Acute pancreatitis. N Engl J Med. 2006; 354(20):2142-50

61. Crew KD, Neugut Al. Epidemiology of gastric cancer. World J Gastroenterol. 2006;12(3):354-62.

62. Bilimoria KY, Bentrem DJ, Wayne JD, Ko CY, Bennett CL, Talamonti MS. Small bowel cancer in the United States: changes in epidemiology, treatment, and survival over the last 20 years. Ann Surg. 2009;249(1):63-71.

63. Miller G, Boman J, Shrier I, Gordon PH. Etiology of small bowel obstruction. Am J Surg. 2000;180(1):33-6.

64. Sangster GP, Ballard DH, Nazar M, Tsai R, Donato M, D’Agostino HB. Multimodality imaging review of Anorectal and perirectal diseases with histological, endoscopic, and operative correlation, part l: anatomy and neoplasms. Curr Probl Diagn Radiol. 2019;48(5):494-508.

65. Ballard DH, Sangster GP, Tsai R, Naeem S, Nazar M, D'Agostino HB. Multimodality imaging review of Anorectal and perirectal diseases with clinical, histologic, endoscopic, and operative correlation, part II: infectious, inflammatory, congenital, and vascular conditions. Curr Probl Diagn Radiol. 2019;48(6):563-75.

66. Rutkow IM. Demographic and socioeconomic aspects of hernia repair in the United States in 2003. Surg Clin North Am. 2003:83(5):1045-51 v-vi.

67. Ballard DH, Jammalamadaka U, Tappa K, Weisman JA, Boyer CJ, Alexander JS, Woodard PK. 3D printing of surgical hernia meshes impregnated with contrast agents: in vitro proof of concept with imaging characteristics on computed tomography. 3D Printing Med. 2018;4:13.

68. Ballard DH, Weisman JA, Jammalamadaka U, Tappa K, Alexander JS, Griffen FD. Three- dimensional printing of bioactive hernia meshes: in vitro proof of principle. Surgery. 2017;161:1479-81.

69. Ballard DH, Mazaheri P, Oppenheimer DC, et al. Imaging of abdominal wall masses, masslike lesions, and diffuse processes. RadioGraphics. 2020. Ahead of print. https://doi.org/10.1148/rg.2020190170.

70. Krauel L, Fenollosa F, Riaza L, et al. Use of 3D prototypes for complex surgical oncologic cases. World J Surg. 2016;40(4):889-94.

71. Bashir U, Moskovic E, Strauss D, et al. Soft-tissue masses in the abdominal wall. Clin Radiol. 2014;69(10):e422-31.

72. Ballard DH, Flanagan ST, Griffen FD. Percutaneous versus open surgical drainage: surgeon's perspective. J Am Coll Radiol. 2016;13(4):364.

73. Witowski JS, Coles-Black J, Zuzak TZ, et al. 3D printing in liver surgery: a systematic review. Telemed J E Health. 2017;23(12):943-7.
74. Ballard DH, Mills P, Duszak R Jr, Weisman JA, Rybicki FJ, Woodard PK. Medical 3D printing cost-Savings in Orthopedic and Maxillofacial Surgery: cost analysis of operating room time saved with 3D printed anatomic models and surgical guides. Acad Radiol. 2019. Ahead of print. https://doi. org/10.1016/j.acra.2019.08.011.

\section{Publisher's Note}

Springer Nature remains neutral with regard to jurisdictional claims in published maps and institutional affiliations.
Ready to submit your research? Choose BMC and benefit from:

- fast, convenient online submission

- thorough peer review by experienced researchers in your field

- rapid publication on acceptance

- support for research data, including large and complex data types

- gold Open Access which fosters wider collaboration and increased citations

- maximum visibility for your research: over $100 \mathrm{M}$ website views per year

At $\mathrm{BMC}$, research is always in progress.

Learn more biomedcentral.com/submissions 